\title{
USE OF STATE-OF-THE-ART METHODS IN THE ARCHITECTURAL DESIGN PROCESS
}

\author{
Dorottya SZILÁGYI, ${ }^{1}$ Nándor BAKAI ${ }^{2}$ \\ ${ }^{1}$ University of Pécs, Faculty of Engineering and Information Technology, Pécs, Hungary, szdo95@gmail.com \\ ${ }^{2}$ Lechner Non-profit Ltd., Budapest, Hungary, nandor.bakai@lechnerkozpont.hu
}

\begin{abstract}
The following article summarizes a research with the intention to demonstrate the challenges that architecture students need to face throughout their design tasks. The study is also meant to contribute to the cognition of state-of-the-art methods that can help students with these emerging problems.

The main source of information was a questionnaire. Students were asked about the duties they accomplish when completing a design, about their adopted design methods and about their thoughts on a future profession. As a complement, Interviews were conducted with professional architects from local studios. This allowed a deeper insight into the requirements that the two sides lay down for each other.

The research charts how computer aided design could affect the difficulties that appear in the architectural design process.
\end{abstract}

Keywords: survey, design methods, building information modeling, computer aided design.

\section{Introduction}

\subsection{The motive of the research}

As architecture students, we often tend to see computer aided design as yet another subject we have to fulfill with a pass mark. We are not invariably aware of the importance of design software, online interfaces and data sources. However, using the latest architectural methodologies currently in practice, we could save a significant amount of valuable energy while performing design assignments - both at the university and professionally. That is why it is so crucial to recognize and adopt the possibilities given to us as soon as possible.

As the projects progress, changes to the plans become more and more costly and difficult to implement. During our student years though, we do not necessarily experience operative construction processes nor the advantages and disadvantages of the various methodologies that influence them. Most of the time the potential in these remains obscure, hence we do not consider what is the most effective way to overcome a particular obstacle.

The research examines the core of these deficiencies and studies various ways to solve the problems that arise in practice.

\subsection{Applied research methods}

The survey is based on contrasting two target audiences. One of the parties is represented by architecture students, while the counterpart is made up of people who actively pursue the profession. Each side was approached through different methods.

The first step was to study the feedback of students. In their case, a quantitative method was used in the form of an online questionnaire. The data obtained this way can be statistically analyzed, the results are clearly demonstrated and the accuracy can be determined.

In the second part of the research, I reached out to professional architects. This time interviews were carried out, acquiring deeper, more subtle information. These results cannot be quantified, but they complement the measurable data received from the questionnaire. 


\section{Analysis of the questionnaire}

\subsection{Participants' anonymous data}

With the questionnaire, that forms the basis of the research, I have focused on architecture students with currently active student status. The form was available for one month on various online platforms via social media. Throughout this time, 55 responses were received, creating a colorful palette of students with different ages, qualifications and experience.

The questions were divided into four main categories. The first segment was intended to map out the most relevant features of the participants. Information was gained about the educational field of those polled, their years spent at the university, prior qualifications and their experiences with architectural design as a subject.

\subsection{Design problems - tasks to be solved}

In the second segment of the questionnaire I examined the structure of a university design project. General tasks that my fellow-students have to complete were gathered and then the extent to which their teachers expect these activities to be carried out was analyzed.

I have also studied the extent to which each task is considered necessary for the development of the students' own design methodology and for creating their plans.

I charted the two different aspects in separate tables and compared the results.

A remarkable difference was shown in the case of surveying existing buildings, historical background research and finding mapping of utilities. In all three instances, students would put much more emphasis on these parts of the work than they would expect them to be from their teachers. A similar contradiction has arisen with regard to the energetic and structural analysis of the planned buildings.

The preference of digital design documentation over the use of manual tools is also significant. This choice happened to be steadily dominant from both perspectives.

\subsection{Design problems - difficulties}

In the third phase of the questionnaire, the semester to complete a design project was divided into three main phases: the periods of conception, elaboration and proposal. Conforming to these, I drew up statements and then I mapped the students' opinions about them.
In the phase of conception, the obtaining of accurate geodetic data proved to be the most difficult. Students find it very complicated to model a site and neighboring buildings.

In the period of elaboration, the loss of time and energy is a major disadvantage which is reflected in the graphical development of the design, and accounts for the lack of software knowledge.

In the phase of proposals, the demand for automation was the most emphatic. During mid-term changes, a significant amount of data is lost due to an inappropriate working method.

\subsection{Solutions - assessing the methodologi- cal knowledge already in use}

In the fourth segment of the questionnaire, I studied students' awareness of accessible tools that might solve the problems arisen. I examined the methodological knowledge they currently hold and surveyed how open they are to applying new innovative solutions.

\subsubsection{Awareness of construction and settle- ment data sources - information collecting methods}

Online map services, which are frequently used in everyday life, proved to be the most common for obtaining site information. Students often search for regulatory plans, but they do not tend to use Local Government GIS or the National Building Register. A few percent of participants rely solely on data given with the curriculum, occasionally supplementing those with personal survey data.

\subsubsection{Modern data management technologies and workstation status}

Among students, digital cameras are one of the most common tools used for surveys. Typically, they work with traditional equipment: measuring tapes, manuals or laser rangers. Some have also met photogrammetry, but this is still a relatively unknown term in education. The main tool for this is the camera, though one of the students also marked the drone as a used accessory.

The idea came up of expanding the opportunities by creating a substantial university hardware park that could help students' work and could make it easier for them to gain experience. They could learn the workflow of remote sensing surveys, try out virtual reality design, or make digital models ready for $3 \mathrm{D}$ printing. 


\subsubsection{Software knowledge}

Being familiar with ArchiCAD is almost a given fact among Hungarian graduate architects.

Only one-third of the participants reported that they used their first learned design software with complete confidence. In general, users are more conscious about the 2-dimensional tools of the programs than the 3-dimensional modeling elements.

The compulsory use of design software chiefly appears in the 5th semester, when students have to design small-scale public buildings (under 500 square meters). Some start applying the programs sooner for minor design tasks, but this is not prevalent. The majority, on the contrary, is not prepared in time for the digital execution of the assigned tasks.

\subsubsection{Students' vision of their future jobs}

I asked students about their thoughts on the expectations that employers might have against newcomers and about the extent to which these requirements are met by the knowledge acquired at the university.

The self-assured use of design software was claimed to be the most important feature. They marked constructive teamwork and high level of engineering and building constructions experience as crucial qualities.

However, they declared that recent graduates cannot really be called to account for expertise in BIM environment nor for being familiar with more than one type of design software.

\section{Analysis of the interviews}

\subsection{The interviewees}

I visited three local offices with different interests and buildups. I was prepared with the same set of questions for each interview, so that I could easily confront the answers.

I asked my questions on four main topics, thus I was able to collect information about the office's work environment, their expectations for newcomers, and the communication and data exchange processes among their employees.

\subsection{Conclusions}

After describing the viewpoint of the interviewees and the students, suggestions for the future can be formulated. By mapping the motives, it can be stated that both students and employers would be open to applying modern architectural methodologies. The potential in innovative tools and optimized work processes is recognized, however, these require a comprehensive, progressive approach. Through the conversations and the questionnaire, some ideas appeared that could help moving the practice forward.

\subsubsection{Work environment development}

ADespite the fact that $80 \%$ of the students are more or less aware of the concept of BIM and would like to learn about it, the interviewees unanimously stated that the Hungarian building industry is not yet ready for full-scale building information modeling. They see the benefits, but all three agreed that this is a complex task, that cannot be brought together with ease, and that would bring drastic changes to the lives of the offices. However, this requires a much more open vision generally. There is also lack of education in this area, thus career starters cannot be expected to have BIM experience.

\subsubsection{Workflow mapping}

Students could gain profitable experience in their own design assignments by deliberately mapping their work processes, knowing how to build project steps and what tools they can pair with each stage. (Learning the methodology of surveys, incorporating new digital devices into the workflow, pairing software for the specific project phases.) To meet these demands, methodological manuals and educational aids can be good options for both students and those interested in the profession.

\subsubsection{Determining the requirements}

When completing design tasks, a frequent problem is that overall expectations are not clear which leads to difficulties in the elaboration of the plans due to different values.

One of the interviewees claimed that the university's job is to give a free hand to planning decisions, not to regulate it, so that creativity is not limited. On the other hand, some share the view that we should not ignore regulations, as they serve as a framework for university projects. They think that it is easier to start an assignment by laying down certain requirements.

\subsubsection{Developing software skills}

Regarding software, a major drawback is that students do not attempt to decipher the developers' train of thoughts. If they did not try to master the solution of certain minor tasks, but to under- 
stand the logic of the software, it might be easier for them to solve design tasks digitally.

\subsubsection{Being aware of specialization possibilities}

Presenting the potential fields of specialization might be a new motivation for students. Many of them leave their studies because they do not feel sympathetic to any of the few main directions (architectural design, construction and interior design).

It can be beneficial to introduce optional fields at the beginning of the studies, such as visualization design, heritage protection, ecology, real estate development or architectural information technology.

\section{Postscript}

With generations changing, the upcoming decade will be a period of searching for paths and solutions for the profession. We can help work out these solutions by embracing the topic, getting to know each other's interests and cooperating. This way we can shape the attitudes of students and professional architects as well.
The study was destined to present the countless modern possibilities we possess, we only have to learn to take advantage of them. We should not consider this cognitive process a burden, rather it is about helping ourselves. This is the way to develop and accommodate state-of-the-art architectural methodologies, and this is in the common interest for all of us.

\section{References}

[1] Országos Területfejlesztési és Területrendezési Információs Rendszer https://www.teir.hu/

[2] Központi Statisztikai Hivatal http://www.ksh.hu/tevekenyseg_kozerdeku

[3] Bartha G., Havasi I.: Térinformatikai alapismeretek. Miskolci Egyetem Földtudományi Kar, Miskolc, 2011. 3.

[4] Rhind, D.: Understanding G.I.S., Environmental Systems Research Institute, 1990

[5] Bácsatyai L., Márkus I.: Fotogrammetria és távérzékelés. Nyugat-Magyarországi Egyetem Erdőmérnöki Kar, Sopron, 2001, 11-14.

[6] Zagorácz M., Szabó B.: BIM kézikönyv. I. kötet, Lechner Nonprofit Kft., Budapest, 2018, 48-51. 